\title{
EL DERECHO PENAL ENTRE LOS ANTIGUOS MAYAS
}

\author{
Al Dr. Mario de la Cueva \\ Ana Luisa Izquierdo \\ Centro de Estudios Mayas
}

\section{Introducción}

Para que un grupo social tenga la posibilidad de subsistir, todos sus miembros han de conducir su acción de acuerdo con una multitud de normas que la comunidad haya escogido entre las alternativas de conducta humana e incorporado a su cultura como formas válidas de comportamiento. Todas las reglas que regulan la vida social tienen un carácter específico determinado por sus rasgos distintivos; así, hay normas morales, religiosas, de urbanidad, de trabajo y jurídicas o legales entre otras.

El objetivo de este ensayo es referimos sólo a las normas legales que reglamentaron la conducta de las personas entre los mayas prehispánicos. No pretendemos hacer un catálogo de ellas, sino únicamente explicar las características fundamentales de su Derecho Penal, como un intento de conocer parte de su sistema legal, partiendo del supuesto de que los mayas tenían un Derecho complejo, una institución sólidamente constituida que no debe ser considerada como "primitiva". Además, esta investigación puede ayudarnos a conocer la naturaleza política de la sociedad maya.

Algunos conceptos fundamentales de la jurisprudencia contemporánea no pueden ser aplicados a pueblos cuya evolución del Derecho no se fundamenta en la tradición occidental de donde estos surgen, ni tiene el grado de complejidad de los sistemas legales actuales. Su uso implicaría negar la existencia de elementos como los tribunales por ejemplo, e incluso llegar a aseverar que estos pueblos no tuvieron Derecho. Por ello hemos escogido una amplia definición de ley surgida de la antropología, que puede ser aplicada a pueblos con un sistema jurídico esencialmente distinto al de los 
occidentales contemporáneos, ya sea que hayan o no desarrollado un sistema de escritura.

Hoebel en su obra The law of primitive man, después de realizar una evaluación de los diversos criterios antropológicos en lo referente al Derecho, concluye que "Una norma social es legal si su incumplimiento o infracción se ve regularmente amenazada con la aplicación de la fuerza física por un individuo o grupo que posee el privilegio, reconocido por la sociedad, para actuar". ${ }^{1}$ Tal concepción se funda en la jurisprudencia contemporánea partiendo del pensamiento de Benjamín Cardozo, quien encuentra cuatro elementos esenciales para que un precepto sea tomado como jurídico; éstos son: normatividad, regularidad, obligatoriedad y la existencia de tribunales. Estos puntos, con un contenido específico, los hemos tomado como guía para diferenciar las normas jurídicas de todos aquellos preceptos que seañlan la conducta en una sociedad.

Por norma entendemos los patrones de comportamiento que la sociedad ha desarrollado y que han sido considerados como válidos por el grupo. La regularidad es la necesidad de la existencia de precedentes que ejemplifiquen el hecho de la constancia en la aplicación de esta norma. Los tribunales son considerados como el grupo de personas en las cuales la sociedad ha depositado su confianza para que decidan la culpabilidad de las acciones de sus miembros e impongan los castigos merecidos; este grupo de individuos no tiene que ser necesariamente permanente, ni su oficio ser el único al que se dediquen, puede participar cualquier miembro de la comunidad con tal de que sea elegido para dicho acto o que su propia situación en el grupo le haga tener ese privilegio. La obligatoriedad es la fuerza que la ley conlleva para que la sociedad la haga cumplir y castigue las violaciones; sin embargo, hay grados y maneras de coerción y sólo algunas formas de ella son legales; "La esencia de la coerción legal es que es socialmente aceptada para la aplicación del poder físico, de hecho sólo por un grupo privilegiado, por una legítima causa, de una manera legítima y en un tiempo legítimo." 2

Algunos antropólogos coinciden en definir el Derecho haciendo explícito este último principio fundamental, entre ellos Herskovits y Radcliffe-Brown; este último sostiene que "El campo del Derecho será considerado... como semejante al de las sanciones legales organizadas." ${ }^{3}$

1 Edward Adamson, Hoebel, The law of primitive man. A study in comparative legal dynamics, Harvard University Press, Cambridge Mass, 1954; p. 28. 2 Ibidem, p. 27.

3 A.R. Radcliffe-Brown, Estructura y función en la sociedad primitiva, 2a. 
Siguiendo el criterio de los elementos conjugados del pensamiento de Cardozo hemos reunido aquellas leyes que regían la vida cotidiana de los mayas en el siglo XVI, pero como ya hemos dicho, concretamente lo que se refiere al Derecho Penal, o sea todas aquellas reglas que protegen la vida, la personalidad y la propiedad, así como las que garantizan la subsistencia y buena marcha de instituciones como el matrimonio, la familia, la religión, el gobierno y la organización social. ${ }^{4}$

Los rasgos peculiares del Derecho Penal en las tierras bajas del área maya y los de las tierras altas son esencialmente semejantes; esto lo demostraremos al ejemplificar cada una de las características apuntadas con las noticias que tenemos acerca de las normas legales acostumbradas en las diversas regiones. Dichas semejanzas nos permiten una generalización a toda el área, que pone de manifiesto la unidad cultural de los mayas. Esto no quiere decir que no existan algunas diferencias en lo que sucedía en el campo jurídico entre los mayas de una y otra región, ya que, por ejemplo, tenemos diversos grados de valoración de un mismo delito dentro de una jerarquía semejante, varias formas de aplicar la pena de muerte a violaciones legles iguales, distintos manejos de las condiciones del delito; mientras en un lugar determinada situación era tomada como agravante, en otro no.

Los antropólogos piensan que la forma más válida de acercamiento a las normas legales que rigen la conducta del hombre, dentro de un determinado contexto social en el que no existe una codificación sistemática de las leyes, o como en el caso de los mayas donde no podemos negar su existencia ni tampoco afirmarla, se debe hacer por medio de casos en los que se observe la reacción dinámica real de la sociedad ante los hechos delictivos. En cuanto a los mayas sólo contamos con descripciones de las normas que estuvieron vigentes, ya que es inexistente la descripción de casos concretos, con excepción de ambiguas informaciones de hechos en el plano abstracto del deber ser; sin embargo, éste es el único modo de conocer tal aspecto de la cultura no material de los mayas prehispánicos.

La otra limitación, que es necesario expresar, es que los testimonios que sobre las normas jurídicas han llegado hasta nosotros, están vistos desde un contexto cultural esencialmente diferente al indígena,

ed., trad. Ångela Pérez, pról. E.E. Evans Pritchard y Fred Eggan, Ediciones Península, Barcelona, 1974; (Historia, Ciencia y Sociedad, 9); p. 241.

4 Bronislaw Malinowski, Crimen y costumbre en la sociedad salvaje, 3a. ed., trad. M. T. Alier, Ediciones Ariel, Barcelona, 1971; (Col. Ariel Quincenal, 15); p. 81 . 
por lo que contamos con una descripción de lo que vieron, o se enteraron los cronistas, con valores occidentales.

En relación a la península de Yucatán, Fray Diego de Landa escribió noticias aisladas del Derecho Penal; juzga que los mayas usaban ciertos preceptos con carácter de ley y sostiene que "Tenían leyes contra los delincuentes y las aplicaban mucho..." " Aunque no pone especial empeño en tratar el tema ni considerarlo cuando habla del gobierno, sí hace énfasis en el castigo a ciertos delitos para poner de manifiesto la rigidez de las penas; no hace una jerarquización de ellas y aclara muy poco en lo referente a las condiciones de su aplicación. Narra un caso de delincuencia en la familia Tutul Xiu y otros de los que fueron protagonistas los Cocomes.

La fuente con la más valiosa información sobre el Derecho de los mayas prehispánicos es la Relación escrita por Gaspar Antonio Chí en 1582 por orden de Guillén de las Casas, Gobernador y Capitán general de Yucatán, quien pidió conocer las normas legales indígenas que todavía sobrevivían en su época. El valor de dicha obra radica en el hecho de que su autor era originario de $\mathrm{Yu}$ catán y que pasó los primeros años de su vida en un ambiente indígena, ya que tenía trece años cuando se realizó la Conquista. Aunque no hay que olvidar que en el momento en que escribió tenía mucho tiempo en contacto con la cultura de los españoles, trabajando a su servicio. Sánchez de Aguilar da testimonio de sus actividades como intérprete del juzgado mayor de Yucatán, y narra que: "El defendía a los indios en sus disputas, presentaba y escribía peticiones..." ${ }^{6}$ Así, en cuanto al Derecho, esta Relación es la fuente que debemos considerar como más directa puesto que su autor se encontraba en tiempo y espacio más cerca de la cultura indígena que cualquier otro cronista de su época; además, estaba muy familiarizado con la mentalidad maya acerca de los asuntos jurídicos por el puesto que desempeñaba.

A pesar de ello, en su documento, no hace diferencia entre ley y costumbre; a todas sus descripciones les aplica un mismo adjetivo, inicia su obra diciendo: "Relación de algunas de las costumbres de la gente de la provincia de Yucatán", ${ }^{7}$ y concluye "Los indios de la

5 Fray Diego de Landa, Relación de las Cosas de Yucatán, 9a. ed., introd. Ångel María Garibay, Porrúa, México, 1966; (Biblioteca Porrúa, 13); p. 6.

6 Alfred M. Tozzer, Landa's Relación de las cosas de Yucatán, A translation, Edit. with notes, Papers of the Peabody Museum of American Archaeology and Ethnology, Vol. XVIII, Harvard University, Cambridge Mass., 1941; p. 45.

7 Gaspar Antonio Chí, Relación en Tozzer, op. cit., p. 230. 
provincia de Yucatán tienen éstas y otras costumbres; muchas de ellas se han perdido, pero algunas todavía hoy las tenemos." 8

Se dice que Gaspar Antonio Chí fue el informante de Landa ${ }^{9}$ y quizá así sucedió, aunque en lo que se refiere a las normas jurídicas parece no haber sido tal, ya que de la comparación de los textos de ambos se desprende que cada uno conoció los hechos de diferente forma; de este modo, a pesar de que los testimonios coinciden en lo fundamental, registran diferentes formas de castigo a un mismo delito, así dicen que para el adúltero con todas las agravantes de la ley, disponían la muerte; Chí afirma que flechándolos y Landa que lanzándole al delincuente una piedra desde lo alto. ${ }^{10}$

En lo que se refiere a normales legales, la Relación de Chí fue aprovechada por López Cogolludo en la redacción de su obra Historia de Yucatán, por la cual fue conocido el documento de manera indirecta, hasta su descubrimiento en el Archivo de Indias de Sevilla, realizado por France Scholes.

La información más temprana que tenemos sobre la población precolombina de Guatemala fue recopilada por Fray Bartolomé de Las Casas en su Apologética historia sumaria. En el pensamiento del autor, expresado en dicha obra, se distingue la diferencia que establece entre algunos preceptos que seguían los mayas y las normas de carácter jurídico que los regían; así, expresa: "Otras muchas buenas costumbres y leyes y orden buena de gobierno tenían las gentes de aquellas provincias..." 11 Cuando hace relación de las leyes que reglamentaban la vida social en diversos sitios de Guatemala, sólo se refiere a normas de carácter jurídico; explica los delitos y las penas que usaban aplicar. Sin embargo, en el momento en que se refiere a las leyes de La Verapaz incluye reglas tanto de índole moral como legal, manifestando su formación escolástica; dentro de un mismo capítulo explica normas éticas y jurídicas, relacionándolas con el Decálogo y demostrando que estos indígenas seguían principios semejantes a los de los Diez Mandamientos del cristianismo.

Años más tarde, para su Monarquía Indiana, Fray Juan de Torquemada se valió, al parecer, de la obra de Las Casas y utilizó su información al escribir sobre las leyes de Guatemala. Posiblemente

8 Ibidem.

9 Tozzer, op. cit., p. 44.

10 Chí, op. cit., p. 231.

Landa, op. cit., p. 53.

11 Fray Bartolomé de las Casas, Apologética Historia sumaria, Ed. prep. por Edmundo O'Gorman, 2 vols., Instituto de Investigaciones Históricas, UNAM, México, 1967; (Serie de Historiadores y Cronistas de Indias, 1); Vol. II, p. 504. 
a través de ella Fuentes y Guzmán conoció estos mismos datos que tomó y, haciendo cierta evaluación de ellos, expresó su propia interpretación en el libro Historia de Guatemala o Recordación florida. También en algunos documentos del siglo XVI y XVII, como las Relaciones de Yucatán, encontramos testimonios acerca de las normas legales de los mayas, pero éstos son muy limitados y se hallan sumamente fragmentados.

\section{Las características fundamentales de su Derecho Penal}

El cuerpo general del Derecho en la sociedad maya, se formó a través del tiempo cuando algunas costumbres adquirieron tal rango de valor que fueron consideradas básicas para mantener el orden social, por lo cual fueron elevadas al nivel jurídico por la sanción de la comunidad; o sea, nos encontramos ante un Derecho que surge directamente de la costumbre y no de una legislación. Sin embargo, no todas las normas legales que regulaban la conducta de los mayas tuvieron como fuente formal la costumbre, sino que podemos hablar de algunas normas que surgieron por una promulgación específica. A este respecto Landa escribe que "Los señores regían el pueblo concertando los litigios, ordenando y concertando las cosas de sus repúblicas" ${ }^{12}$; de Guatemala Las Casas testifica que "Aquel rey supremo tenía ciertos varones principales del consejo, los cuales tenían cargo de la justicia y determinaban lo que se debía hacer en todos los negocios." ${ }^{13}$ Algunas de las normas dictadas por las autoridades eran legales en la medida en que tenían este carácter, ya que eran reglas cuya violación causaba la reacción represiva de la sociedad.

Así, podemos decir que en el cuerpo del sistema jurídico maya coexistían las leyes que la comunidad había gestado de una manera inconsciente y las que habían surgido de un acto jurídico intencionado, que pueden ser llamadas legislación.

En la sociedad maya el Derecho penal era manejado por el Estado, quien determinaba cuándo y por qué medios iba a actuar ante un hecho; o sea, disponía los procesos y las sanciones.

En cada una de las comunidades mayas, las autoridades, según su rango, tenían ciertas atribuciones legales.

Diversos autores afirman que en la escala más baja de los puestos oficiales estaba el tupil, nombre de origen náhuatl que en el Dic-

12 Landa, op. cit., p. 35.

13 Las Casas, op cit., Vol. II, p. 500. 
cionario de Motúl se traduce como "alguacil"; ${ }^{4}$ Chí, en su Relación, relata que tenían "alguaciles que siempre estaban ante los jueces"; $;{ }^{15}$ por ambos testimonios podemos decir que se trata de personas que estaban involucradas en el asunto de la justicia, pero que no tenían autoridad legal, ya que su papel consistía en estar con los jueces durante las diligencias para ejecutar las órdenes que estos les daban. Entre otras cosas eran los encargados de ir a capturar a los culpables, pedir su presencia a los testigos o buscar pruebas, por lo que puede comparárseles con un policía, cargo que entre los mayas era honroso y al que podía aspirar cualquier persona del pueblo con méritos suficientes. Empleados semejantes los hubo también en Guatemala "donde tenían otros ministros de justicia y oficiales que tenían cargo como alguaciles, de llamar o convocar las gentes o personas particulares cuando lo mandaban". ${ }^{16}$

De acuerdo con los cronistas, entre los funcionarios públicos había personas que tenían cierta responsabilidad y alguna autoridad para impartir justicia; esta facultad les era otorgada por la autoridad civil del poblado, que recibía el nombre de batab. Sobre esto Chí relata: "Para oír los litigios y las demandas públicas, el señor tenía un gobernante o persona de rango en las ciudades"17 y Las Casas explica que en "las grandes poblaciones había prepósitos o tenientes del señor. Estos tenían la jurisdicción limitada que el señor les concedía." 18 Es posible que dichos representantes de la autoridad civil con funciones judiciales, sólo hubiera en aquellos poblados en que el número de habitantes obligara a los gobernantes a delegar ciertas facultades en una o varias personas, o que estuvieran eregidos en centros de poder por lo que su aparato político tuviera la necesidad de funcionarios públicos profesionales. Tozzer lo identifica con el ah kulel, que según el Diccionario de Motul era "cierto oficial de la república, menores que los ah cuch cabe, mayores que los tupiles, abogados, mediadores y terceros entre algunos... veedor como maestre sala". ${ }^{19}$ Estos magistrados eran personas de "rango" o principales; o sea, su origen era noble y además "hasta que muriesen no los quitaban, y en la subrogación y postura de otros siempre se tenían respecto a sustituir el más digno y provechoso para el bien común... porque había ciertos grados de oficios menores en que

14 (Fray Antonio de Ciudad Real), Diccionario de Motul, Ed. Juan Martínez Hernández, Mérida, 1929; p. 873.

15 Chí, op. cit., p. 231.

${ }_{16}$ Las Casas, op. cit., Vol. II, p. 512.

17 Chí, op. cit., p. 231.

18 Las Casas, op. cit., Vol. II, p. 500.

19 Motul..., op. cit., p. 93. 
primero se experimentaban; por manera que, cuando llegaban a subir en el estado de prefecto o teniente, ya era viejo y de madura edad." ${ }^{20}$ Por lo tanto, los requisitos para obtener este puesto eran: el linaje, el haber desempeñado otros puestos públicos y el haber actuado con gran rectitud en el ejercicio de sus funciones.

Nos han quedado numerosos nombres de las personas que habían desempeñado el puesto de ah kulel como le designaban en la lengua maya de Yucatán, por ejemplo, por la Crónica de Calkiní sabemos quiénes habían desempeñado el cargo en los diversos sitios donde tenían soberanía los Ah Canul.

Es muy confusa la información con que contamos acerca de las altas autoridades, estatales aunque se pueden distinguir dos maneras de gobernantes: unos a los que se menciona como caciques, o señores inferiores o prefectos de los pueblos, y otros a los que se designa como monarca, rey o señor soberano o señor simplemente. Con los primeros nombres los cronistas debieron referirse a la autoridad política de cada pueblo, ya sea independiente o sujeto a la hegemonía de un gobernante territorial. En el campo del Derecho, éste tenía un amplio poder jurídico, tanto para legislar, como para juzgar o sancionar, con una extensa libertad para manejar las normas, limitada sólo, en ciertas cuestiones, cuando estaba sujeto a la soberanía de un gobernante de la provincia a la que pertenecía.

Tozzer identificó dicha autoridad con el batab basándose en el Testimonio de Homun que dice: "Batab Che, Cacique de Xocchel";" en el Chilam Balam de Chumayel aparece continuamente la palabra batab asociado a nombres propios, de tal manera que Roys lo traduce como jefe. Suponemos que esta palabra del maya yucateco es un término genérico con el que se designó a los diversos jefes políticos, tanto locales como de una provincia indistintamente, por lo que aparece en los documentos escritos en maya y en algunos en castellano, sin que podemos saber a cuál de las altas jerarquías políticas se están refiriendo. Esto lo podemos comprobar tomando como ejemplo la Relación de Cinanche que narra que "El gobierno suyo y el general era que tenían señores y los reconocían por tales que llamaban batabes que es lo mismo que señores". ${ }^{21}$

Para el desempeño de sus funciones el batab contaba con un consejo del pueblo al que sometía todos los asuntos concernientes

20 Las Casas, op. cit., Vol. II, p. 501.

${ }^{21}$ Relaciones histórico-geográficas de las Provincias de Yucatán, en Col. de Documentos inéditos relativos al descubrimiento, conquista y organización de las antiguas posesiones de Ultramar, 2a. Serie, Vols. 11 y 13, Establecimiento Tipográfico "Sucesores de Rivadeneyra", Madrid, 1898, 1900; Vol. I, p. 138.

* Tozzer, op. cit., p. 62. 
al gobierno, incluso aquellos de carácter jurídico. Creemos que en el campo del Derecho Penal, los miembros de esta asamblea, ni como individuos ni como institución tenían algún poder legal, sino sólo colegiados con el batab, excepto en aquellos casos en que el protagonista del delito era el mismo gobernante. A cada consejero se le designaba como ah cuch cab en el maya de Yucatán y según la Relación de Dohot "este era como el señor que llaman ellos batab que tenía su boto como regidor en cabildo y sin su boto no se podía hazer nada, y el día de oy se usa en cada pueblo ay dos o tres de estos". 22

$\mathrm{La}$ otra autoridad estatal que mencionan los cronistas era la dignidad política más encumbrada, este jefe territorial tenía poder en todos los campos del gobierno, incluso en el religioso. Podía legislar normas que rigieran no sólo en el poblado en donde residía, sino en todas aquellas comunidades que estaban bajo su hegemonía. Además ejercía como supremo juez de las graves cuestiones legales de su ciudad como batab de ella; también aplicaba la ley a las autorida. des superiores de otras poblaciones y resolvía todos los litigios que se daban entre los miembros de dos comunidades diferentes.

Para ejercer su autoridad tomaba el parecer de un grupo de personas que algunos españoles llamaron "Supremo Consejo" o "Supremo Tribunal". Las Casas, tratando del señor La Verapaz, explica que "Ayuntábanse con él en la casa real o consejo cuando los llamaban. Trataban y determinaban las cosas primero que pertenecían al culto divino; las de la guerra y de la paz, y las cosas otras necesarias y convenientes a sus repúblicas, y ésta era cosa maravillosa ser tan amigos de no hacer cosa sin mucho acuerdo y consejo... Cognocían también y determinaban cerca de los delitos que se cometían graves..." ${ }_{23}$ Este batab era llamado halach uinic "hombre verdadero", que se traduce en el Diccionario de Motul como "obispo, oidor, gobernador, provincial o comisario". ${ }^{24}$ Las provincias gobernadas por un halach uinic de que tenemos noticias, fueron Ceh Pech, Maní, Sotuta, Cochuah, y quizá también Ah Kinchel, Chetumal y Champotón. ${ }^{25}$

Como en las sociedades prehispánicas no había una disociación entre lo civil y lo religioso es claro que las jerarquías políticas cumplieron también funciones religiosas. Así vemos que el máximo diri-

22 Ibidem, Vol. II, p. 211.

23 Las Casas, op. cit., Vol. II, p. 512.

24 Motul..., op. cit., p. 369.

25 Ralph Roys, "Lowland maya native society at spanish contac", Hand. book of Middle American Indians, Vol. 3, University of Texas Press, Austin, 1965 ; p. 669. 
gente, el halach uinic, concentra poderes civiles y sagrados, que los ah cuch caboob son consultados en asuntos concernientes a la religión y quizá hasta el batab tuvo algún papel en este aspecto. Esto nos permite afirmar que el alto clero maya tuvo atribuciones jurí. dicas de las que posiblemente estuvieron relegados los demás sacerdotes, aunque podían amenazar al malhechor con desencadenar sobre él las fuerzas malignas sobrenaturales y exigirle expiaciones rituales.

Cuando un sacerdote estaba involucrado en un delito, ya sea como demandado o como parte actora, en tanto perteneciente a la nobleza, sólo podía ser atendido por los tribunales encabezados por las altas autoridades políticas que también eran sacerdotes de gran rango.

Los funcionarios públicos que tuvieron en sus manos la autoridad para manejar el Derecho, tenían una cierta amplitud para utilizar su propio criterio judicial; por un lado, por más rígidas que hayan sido las leyes que la costumbre impuso como tales, si éstas no estuvieron codificadas se prestaban a múltiples posibilidades de interpretación, y por otro lado, aun cuando los personajes de la jerarquía de los halach uinicoob debieron tener derecho de veto sobre las decisiones de sus subalternos, dentro de los límites que su responsabilidad jurídica les establecía, cada una de las autoridades tenía un ámbito extenso de independencia para ejercer sus funciones por su propio fuero.

Ahora bien, tampoco las decisiones legales estaban totalmente sujetas al libre arbitrio de los funcionarios judiciales, sino que formaban cortes o tribunales en el sentido antes expresado. La demanda de la intervención de la justicia se hacía ante el ah kulel quien escuchaba el asunto que los hacía llegar ante él, entonces gestionaba la formación de un tribunal invitando a que acudieran algunos miembros de la comunidad como abogados o como testigos. ${ }^{26}$ Generalmente, los asuntos le eran comentados al señor, quien decidía si intervenía en el tribunal convocado o dejaba que su delegado lo llevara a su término.

Con este tribunal, efímero e improvisado, el juez podía absolver o condenar; aunque su papel más frecuente era funcionar como tribunal de lo contencioso, poniendo de acuerdo a los disputantes. De acuerdo con lo que Fuentes y Guzmán explica, el ah kulel "Tenía amplia jurisdicción y muy suprema sobre los súbditos y vasallos de aquel gobierno; más con limitación y cierto modo, en que en los casos graves y dudosos, y en los que, ocurriendo al tribunal de aquel teniente, siendo contra Ahau o persona consti-

26 Chí, op. cit., 231. 
tuida en grande puesto: no podía pasar; sin ser delito, a determinar y dar sentencia, ni aún a la averiguación y a la pesquisa, sino que estos se remitían ante el rey su consejo: adonde sólo podían pasar y ser tratadas aquellas causas". ${ }^{27}$ De este modo sólo podía resolver asuntos no serios, pero no conocemos el límite de su competencia; ponía de acuerdo a los litigantes, obligaba a que se cumpliera la norma violada, cuando esto era posible, imponía indemnizaciones a satisfacción del agraviado, tasaba las multas, o hacía ejecutar algún otro castigo menor; pero en las cuestiones en que la gravedad de la infracción a la ley era objeto de penas como la esclavitud y la muerte, debió intervenir el señor local, formándose una nueva instancia.

Los ah cuch caboob también se constituían en un tribunal cuando se reunían a deliberar; en el caso en que se congregaran con el halach uinic o señor soberano, sabemos que "eran por ello llamados los prefectos de los pueblos y los más ancianos vecinos y que eran cabezas de linaje o padres de familia y algunas veces llamaban a los tales cuando se trataban de las penas y prohibiciones de los graves delitos". ${ }^{28}$

Una aclaración referente al tipo de asuntos que eran ventilados por dicha corte la encontramos en la Recordación florida, en el párrafo de Fuentes y Guzmán antes transcrito. Por lo tanto, era competencia de tal corte todo delito cometido en perjuicio de las personas o las instituciones políticas o religiosas. Posiblemente también fueron ventiladas infracciones cometidas por los nobles, lo que nos lleva a pensar que a aquellos tribunales reunidos por el $a h$ kulel que trataban asuntos de carácter menor, acudían las gentes del pueblo común. Esto no es remoto ya que entre los náhuas, además de otros tribunales, tenemos el Teccalli que manejaba los asuntos no graves de los macehualtin y el Tlaxcitlan que tenía competencia en los casos de los pipiltin y en asuntos capitales de los macehualtin. ${ }^{29}$

Además de todos estos funcionarios en los que hemos reconocido atribuciones jurídicas, sabemos por el padre Las Casas, que a semejanza del Altiplano Central, en Guatemala, en los mercados; "presidía un juez o alcalde o fiel y secutor que tenía cargo y oficio de ver y tasar los precios de las cosas, y para que ninguna hiciese a otro agravio, y para averiguar y determinar las dudas o contenciones

27 Francisco Antonio de Fuentes y Guzmán, Recordación florida en: Obras históricas de.... Ed. y estudio preliminar Carmelo Sáenz de Santa María, 3 vols., Atlas, Madrid, 1969-1972; (Biblioteca de Autores Españoles, desde la formación de la lengua hasta nuestros días, 230, 251, 259); Vol. II, p. 289.

28 Las Casas, op. cit., Vol. II, p. 513.

29 Alfredo López Austin, La constitución real de México T'enochtitlan, Instituto de Historia: Seminario de Cultura Náhuatl, UNAM, México, 1961; p. 98. 
que naciesen por razón de las mercaderías". ${ }^{30}$ Dicho personaje debió tener una autoridad limitada a cuestiones mercantiles, en las que su papel fundamental debió ser el de conciliador y sus sentencias reducidas a imponer indemnizaciones y multas. No sabemos cual era la medida de su poder en este campo del Derecho, ni si reunía algún tipo de tribunal o turnaba ciertos casos a otras autoridades con mayor poder legal.

A pesar de que, como hemos expresado a través de este ensayo, el Estado tenía en sus manos la administración del Derecho por medio de funcionarios públicos e instituciones claramente definidas en sus atribuciones legales, todavía podemos encontrar la supervivencia de costumbres que señalan un sistema más antiguo en el que predominó la justicia privada, como la libre determinación de los particulares para pedir la intervención de la justicia en ciertos delitos.

Una expresión de estas supervivencias es el hecho de que todas las infracciones en que no se ponía en peligro la solidez de las instituciones políticas o religiosas y en las que además el acto no había causado la exteriorización de la vergüenza pública no se perseguían de oficio, sino que el afectado y su familia resolvían si pedía la intervención de la justicia o no. Por lo tanto, en determinadas circunstancias, quedaban impunes violaciones a la ley como el adulterio, el amasiato, el latrocinio, las heridas y hasta el homicidio. Las Casas, refiriéndose al adulterio, comenta que "Algunas veces dicen los indios que los que eran buenos hombres y pacientes no decían al señor el pecado de su mujer, sino dábanle un pájaro de los que ellos sacrificaban y decían a su mujer y al adúltero que sacrificasen y se confesasen, y con este sacrificio y confesión se contentaban y no pedían de su injuria otra venganza..." ${ }^{31}$

Asimismo, la justicia maya perseguía habitualmente, sin necesidad de interposición de queja o de acusación, todas aquellas infracciones cometidas contra el Estado o personas que lo representaban, cuestiones que desde el punto de vista maya eran hechos cuya punición era de vital interés general, ya que ponían en peligro la estabilidad social.

Otras manifestaciones de supervivencias de formas legales más sencillas se oponen de manifiesto en algunas infracciones en las que se permitía al ofendido llevar a cabo la ejecución del malhechor, después de realizado el proceso y dictada la sentencia;

30 Las Casas, op. cit., Vol. II, p. 514.

31 Ibidem, p. 522. 
también, a veces, el agraviado tenía la facultad de perdonar al delincuente ante las autoridades competentes para legitimar el hecho. Landa acerca del adulterio, expresa que: "hecha la pesquisa y convencido alguno del adulterio, se juntaban los principales en casa del señor, y traído el adúltero atábanlo a un palo y le entregaban al marido de la mujer delincuente; si él le perdonaba era libre; si no, le mataba con una piedra grande que déjabale caer en la cabeza desde una parte alta". ${ }^{32}$

Cuando cualquiera de las fuerzas públicas con potestad jurídica intervenía, se efectuaba, como primer paso del proceso, la configuración del delito para lo que era necesario que se examinaran pruebas que demostraran la veracidad del hecho. Los ah kuleloob, los bataboob y hasta los halch uinicoob y su consejo acostumbraban pedirlas y analizarlas; acerca de lo cual en la Relación de Motul se explica que: "las aberiguaciones hacian de plano contestigos" 33 .

Reconocemos en la información que nos legaron los cronistas pruebas de carácter presuncional, confesional, testimonial y evidencias materiales.

Las presunciones eran tomadas como medios para demostrar, aunque no plenamente, un hecho, cuando los gobernantes actuaban en función del conocimiento del rumor público, ${ }^{34}$ sin embargo parece que comunmente no se hacía caso de ello, a no ser por tratarse de algo que hubiera causado un escándalo general o que, de alguna forma, estuviera lesionando los intereses del Estado.

Antonio Chí se refiere a hechos en los que, prevía acusación, las autoridades procedían fundándose en circunstancias que daban pábulo a pensar en la probabilidad de una transgresión; así, "Algunas veces, cuando el adulterio no era probado en contra del hombre o a él se le había encontrado a horas inoportunas en un lugar sospechoso, era aprendido y le amarraban las manos atrás, aproximadamente, por un día o algunas horas o le desnudaban o cortaban el pelo, lo que era una gran deshonra, todo esto de acuerdo a la evidencia". ${ }^{35}$

Muchas veces se tenía el testimonio confesional, o sea, que el acusado reconocía expresamente su culpa. En caso de que hubiera pruebas de peso y no aceptara su culpabilidad, empleaban medios represivos para hacerlo decir la verdad; conocemos que a los adúlteros "dábanles tormento de cuerda atándoles reciamente los brazos

32 Landa, op. cit., p. 53.

33 Relaciones..., op. cit., Vol. 1, p. 80.

3. Las Casas, op. cit., Vol. II, p. 502.

35 Chí, op. cit., p. 232. 
atrás por los molledos y dábanles el garrote detrás, y demás desto, si no confesaban, dábanles humo a narices y quemábanlos estando dellos en alto, como se dijo ya. Estos mismos tormentos daban a los ladrones hasta hacerles confesar la verdad". ${ }^{36}$

La confesión religiosa, extrajurídica, usada comunmente por los mayas como un medio purificador, tenía valor como prueba, de tal manera que podía ser utilizada por el que la había escuchado para demandar a una persona de un acto ilegal, como en el caso "que diciendo una mujer en aquella confesión que un hombre había pecado con ella, luego lo acusaba delante del señor, y sin testigos ni otra probación penaban al que la mujer en la confesión declaraba haber sido su cómplice, aunque él lo negase..." ${ }^{37}$

Incluso celebraban careos para enfrentar diversos puntos de vista o escuchar varias versiones, hasta el grado de ir a examinar el lugar de los hechos o convocar numerosas reuniones cuando la disputa así lo requería.

Promovida la demanda, demostrados los hechos y configurado el delito, se continuaba el proceso con determinar a qué autoridades correspondía seguir el juicio de acuerdo a lo que referimos cuando tratamos las competencias en material penal.

En los sistemas legales de algunas culturas de la antigüedad, la culpa se evaluaba en función del resultado de la infracción "es la ley del talión (el pago en la misma moneda en caso de lesiones corporales u homicidio involuntario)", ${ }^{38}$ o sea la culpa atribuida a un delincuente estaba en relación directa al perjuicio material ocasionado. Entre los mayas, el otro punto en el desarrollo del juicio era la consideración de la cuantía del daño provocado, pero al mismo tiempo valoraban la culpa de acuerdo con el grado de culpabilidad del demandado al haber cometido la fechoría; así, nos encontramos ante diversas posibilidades, más o menos rígidas, para castigar un mismo delito, de acuerdo con la responsabilidad habida en la comisión del hecho. La complejidad a que había llegado su sistema jurídico hacía que fueran múltiples los factores considerados para establecer en qué medida se podía atribuir a una persona la culpa por ciertos actos; unos referentes a la persona del delincuente y otros en relación a las circunstancias en que la infracción había sido cometida. Como elementos ajenos al delito, pero estimados

36 Las Casas, op. cit., Vol. II, p. 524.

37 Ibidem, p. 522.

38 Elena Cassin, et. al., Los imperios de antiguo oriente. Del paleolítico a la mitad del segundo milenio, 3a. ed., Siglo XXI, México, 1972; (Historia Universal Siglo XXI, 2); p. 173. 
para dicha evaluación estaban el status social, el sexo y la edad del infractor.

La sociedad maya en el momento de la Conquista estaba organizada en grupos bastante diferenciados; al estamento superior pertenecían las autoridades civiles y religiosas, en la lengua maya de Yucatán se les llamaba almehenoob y formaban una nobleza de linaje poco numerosa. El Derecho en las sociedades antiguas, generalmente, concede privilegios al grupo que tiene el dominio político y religioso, siendo menos rígido en las sanciones que le impone por las violaciones a la ley o permitiéndole, de alguna manera, evadir su responsabilidad ante la justicia. En el caso de los mayas, cuando una persona de condición social elevada se veía en la circunstancia de ser procesada por algún delito, su responsabilidad ante el hecho aumentaba por esta situación, evidencia que Antonio Chí, de la familia de los Xiu, nos da cuando relata que: "Odiaban grandemente este vicio del (adulterio), contra el cual era el castigo en personas de muy alto rango, porque no había perdón para equellos que se encontraban culpables". ${ }^{39}$ Landa al apuntar como sanción para el hurto la esclavitud, comenta: "Y si eran señores o gente principal, juntábase el pueblo y prendido (el delincuente) le labraban el rostro desde la barba hasta la frente, por los dos lados, en castigo que tenían por gran infamia". ${ }^{40}$ En una sociedad como la maya, tal castigo debió aniquilar cualquier ascendiente sobre el pueblo que tuviera el almehen involucrado.

Así como la culpabilidad de una persona por la comisión de un delito aumentaba por pertenecer a una alta condición social, sus derechos eran mayores. Cualquier individuo que violaba una ley en perjuicio de un personaje de alto rango se veía envuelto en una grave carga. ${ }^{41}$

La mayoría de la población pertenecía al estamento que algún cronista define como el "pueblo menudo", ${ }^{42}$ eran los agricultores, pescadores, artesanos y pequeños comerciantes, para quienes el sistema jurídico era más benevolente que con los miembros del grupo dirigente; por ejemplo, el adulterio entre la gente común era un hecho más tolerado.

De estas consideraciones se deriva que entre los mayas existió la desigualdad de los individuos ante la ley a la inversa de como ocurrió en otras culturas. Una razón a esta falta de equidad se

\footnotetext{
$39 \mathrm{Chl}$, op. cit., p. 231.

40 Landa, op. cit., p. 53.

41 Vid nota 29.

42 Landa, op. cit., p. 34.
} 
encuentra en el sistema paternalista de gobierno en el que las autoridades tenían como una de las más importantes obligaciones de su condición social el ser patrón vivencial de conducta.

Además de estimar la posición del individuo en la sociedad para fijar su grado de responsabilidad jurídica también se tomaba en cuenta, como ya apuntamos, el sexo y la edad.

De Yucatán sabemos que cuando una mujer tenía relaciones extra. maritales, su amante era entregado a su marido y éste lo podía perdonar o ejecutar la sentencia y "a la mujer por satisfacción bastaba la infamia que era grande, y comúnmente por esto las dejaban", ${ }^{43}$ esto nos hace expreso que la condición femenina era el motivo por el cual en los procesos, aunque se les consideraba una plena responsabilidad jurídica, eran juzgadas con mayor benevolencia. De la misma manera, la edad también influía en la calificación de los delitos; López Cogolludo afirma que: "la misma pena tenía el que mataba a otro... y si era menor de edad el matador quedaba hecho esclavo".44 No tenemos datos que nos permitan saber, hasta cuándo un varón era considerado adulto, aunque posiblemente, se pueda considerar la plenitud de la responsabilidad jurídica más o menos a los 20 años, edad en que acostumbraban contraer matrimonio.

$\mathrm{La}$ intencionalidad, o sea, la voluntad deliberada que hace que la ley sea violada, o el delito causado por actos independientes a la determinación personal, eran hechos reconocidos por el Derecho maya y contemplados al evaluar el grado de culpabilidad del infractor. Sabemos que "examinando el daño (el juez) mandaba la satisfacción, los amigos y parientes le ayudaban. Las causas de que solían hacer estas satisfacciones eran si mataban a uno casualmente, o cuando se ahorcaba la mujer o el marido con alguna culpa o haberle dado ocasión para ello, o cuando eran causa de algún incendio de casas o heredades, de colmenas o trojes de maíz. Los otros agravios hechos con malicia los satisfacían siempre con sangre y puñadas". ${ }^{45}$ En este párrafo está expresado como la contravención involuntaria a la ley, ya sea accidental, por negligencia e incluso por hechos cometidos en estado emocional de agresividad provocada, eran tenidos como atenuantes de la culpa.

El Derecho maya logró tal grado de evolución que la sola intención, manifiesta de manera expresa, era suficiente para juzgar

43 Ibidem, p. 53.

44 Fray Diego López Cogolludo, Los tres siglos de la dominación española en Yucatán o sea Historia de esta Provincia, 2 vols. Akademische Druck. Verlagsanstalt, Graz, Austria, 1971. Vol. I, p. 237.

${ }^{45}$ Landa, op. cit., p. 41. 
un hecho, ya que, por ejemplo, actos como el estupro tenían como pena la muerte "mas si no había hecho más que intentar la violación sin llegar al efecto le daban por esclavo de resgate, al arbitrio y disposición de la parte agraviada". ${ }^{46}$ En las conspiraciones puestas al descubierto y por lo tanto sólo proyectadas, se analizaba si eran movidas por causa justa y, cuando lo eran trataban de resolver lo que las había ocasionado, pero si "el que levantaba la conspiración contra su príncipe, no probaba y justificaba sus tiranías, era muerto con tormento cruel y secrestados todos sus bienes, y dados por eslcavos sus mujeres y parientes... ${ }^{47}$

A todas estas situaciones, que de alguna manera, atenuaban la culpa y diminuían la pena, debemos añadir varias circunstancias que funcionaban como agravantes del delito. Cabe destacar la reincidencia, que debió ser considerada como una manifestación del fracaso de las fuerzas de la justicia ante conductas nocivas al grupo. El ladrón, "reincidiendo y pasando á tercer latrocinio, incurría en pena de muerte. Mas si era de familia rica y le compraba el calpul á donde pertenecía, pagando por él todos los hurtos que le comprobaban y otra cantidad para el Erario o depósito del Rey, quedaba libre y en esto no había excepción de personas, porque sólo se atendía a que, demás de ser infamia era daño de muchos". ${ }^{48}$ Esto nos muestra que entre los mayas el infractor, aunque en ocasiones anteriores ya hubiera sido procesado y hubiera pagado su culpa, cada vez que repetía el delito acumulaba una mayor gravedad hasta que era merecedor de la pena capital, aun cuando el daño material causado fuera mínimo.

Cuando el atentado se cometía en un lugar sagrado o el cuerpo del delito tenía este carácter, la posición del acusado se agravaba, por lo que se cuenta que "El hurto de las cosas sagradas, profanación de los adoratorios... se castigaba con dura mano, despeñando al reo, y todos los de su familia quedaban en la línea de infames y en esclavitud perpetua". 49

En algunos sistemas legales del pasado, la responsabilidad jurídica ya evaluada, rebasaba el límite de la atribución al individuo concreto, extendiéndose la carga de la culpa a otras personas a las que estaba unido el infractor por pertenecer a una misma comunidad aldeana, a un clan, o a una familia a pesar de que no fueran cómplices o encubridores, esto es lo que Hermann Trimborn, al

16 Fuentes y Guzmán, op. cit., Vol. I, p. 73.

47 Ibidem, p. 72.

48 Ibidem, p. 73.

49 Ibidem. 
analizar el delito en las culturas prehispánicas, ha llamado "responsabilidad solidaria". ${ }^{50}$

En el proceso histórico de los sistemas jurídicos, dicha responsabilidad solidaria se va restringiendo hasta desaparecer totalmente, excluyendo a los demás de cualquier tipo de obligación legal. Entre los mayas esta costumbre estaba reducida a la familia del delincuente; según los cronistas, los actos antijurídicos en que la culpabilidad se hacía extensiva eran: la traición al Estado, el hurto grave o de objetos sagrados, la profanación de lugares dedicados al culto, la tiranía o la malversación de fondos públicos, la piromanía, el plagio o la venta de hombres libres, por lo que les daban la pena capital "y confiscánle todos sus bienes, y a sus hijos y mujeres hacían esclavos". ${ }^{51}$

La extensión de la responsabilidad por ciertos actos delictuosos, entre los mayas, debe explicarse por el hecho de que nunca consideraron la conducta del hombre como algo totalmente individual, sino que ésta tenía cierta interdependencia del núcleo familiar en el que estaba inmerso; así, su concepto de responsabilidad colectiva hacía que, de alguna manera, los individuos emparentados directamente con el malhechor fueran culpados por no impedir las conductas delictuosas; ésta debió ser la justificación social para castigar a esposa y padres. Esto mismo nos puede explicar el castigo extensivo a los hijos en dicha circunstancia, a quienes quizá se consideraba con una educación deformada, por lo que representaban un peligro social inminente al ser potenciales infractores de la ley.

Comprobada la veracidad de los hechos y fijado el grado de culpabilidad del procesado, la autoridad que fungió como juez, con ayuda de los miembros del tribunal que había ventilado el asunto, resolvía el problema planteado y dictaba sentencia, pronunciándola ante el interesado. Sin pérdida de tiempo pasaban a llevar á cabo la ejecución mandada.

Todas las gestiones para resolver un litigio o castigar un delito se hacían sin demora, ni el proceso ni la sentencia se escribían. Es posible que los asuntos trascendentes tardaran unos días en concluirse como resultado de que tenían que ser turnados a las autoridades competentes.

No había recursos de apelación en ningún caso, o sea, era inexistente la posibilidad de recurrir a otras autoridades y pedir su reconsideración a un juez o tribunal superior. Algunos auto-

50 Herman Trimborn, El delito en las altas culturas de América, Universidad Nacional Mayor de San Marcos, Lima, Perú, 1968; (Comentarios del Perú, 9); p. 53.

${ }_{51}$ Las Casas, op. cit., Vol. II, p. 502. 
res han creído que existía dicha alternativa en virtud de que ciertas cuestiones eran oidas por un funcionario, pero al configurarse el delito, o antes, si el hecho era grave, se turnaba a otras autoridades ya que la competencia de las primeras era insuficiente para darle solución.

En Yucatán "Los jueces podían recibir presentes de los disputantes, tanto de un lado como de otro, estos presentes servían como memorial e instrumento legal". ${ }^{52}$ Con estas palabras se hace referencia a la costumbre de dar regalos como estipendio, a ciertas autoridades cuando se dirimía un pleito; en caso de una demanda la parte actora debió costear el proceso de la misma manera. Seguramente sólo los funcionarios del rango de los ah kulel y quizá incluso los batab recibían estas costas, pero ya en el momento en que lo trataban las altas autoridades, no se daba remuneración.

Todas las sentencias conllevaban implícito un castigo, cuya magnitud se determinaba en relación directa con el nivel de responsabilidad habido en el hecho y con las circunstancias personales del inculpado, como ya explicamos. Contamos con noticias de una numerosa gama de castigos consignados por los diversos cronistas, muchos de los cuales aparecen ante nosotros como contradictorios; sin embargo, esto se debe a la gran cantidad de castigos que había para un mismo delito en circunstancias diferentes, que no aclaran los cronistas.

Como en toda sociedad, entre los mayas las sanciones tenían como intención mantener el orden social; evitando que sus miembros cayeran en conductas antisociales y que los delincuentes reincidieran en la violación de los preceptos jurídicos. Por lo tanto, cada uno de los castigos debía tener un carácter ejemplar que produjera en los individuos el temor a los actos de represión que la comunidad, por medio de sus autoridades, imponía. Aunque todas las sanciones legales tienen este sentido, entre los mayas se hacía más evidente por el hecho de que las ejecuciones eran públicas. La Relación de Motul aclara que: "a los adúlteros castigaban con pena de muerte, a los cuales ponían en alto en parte pública donde pudieran ser vistos de todos". ${ }^{53}$

Además del sentido preventivo y correctivo de las sanciones, en la sociedad maya éstas debieron haber tenido un carácter mágico de purificación, necesario en una comunidad en la que cualquier delito es también un "pecado" contra las fuerzas superiores, el

52 Chí, op. cit., p. 231.

53 Relaciones..., op. cit., Vol. I, p. 80. 
cual, por ello, despliega una energía maligna en la colectividad. En el pensamiento maya delito y "pecado" están tan identificados que, tanto para actos de carácter moral como jurídico, se utilizaba en el maya-yucateco el término keban que está traducido en el Diccionario de Motul como "pecado en general... pecados que se hazen de noche, como combites, bevidas, y bailes... pecado de hurto, de soberbia, de amancebamiento, etc." 54

$\mathrm{La}$ intencionalidad purgatoria de los castigos no aparece en los testimonios escritos sobre los mayas prehispánicos; en estas informaciones las sanciones se nos revelan sumamente secularizadas, lo que parece tener su origen en la visión de las sanciones como actos civiles, que debieron tener los cronistas.

Los medios que cada sociedad utiliza para reprimir las conductas delictivas y procurar el cumplimiento de las normas legales son violentos en mayor o menor medida; entre los mayas el rigor con que procedía la justicia era manifiesto, de tal manera que mostraba a la colectividad el poder de sus autoridades. Una sanción frecuentemente aplicada era la muerte, en una gran diversidad de formas crueles, siempre y cuando fuera un delito comprobado y con todas las agravantes de la ley. Entre los muchos ejemplos que podemos citar están la lapidación, el sacarle los intestinos por el ombligo, el flechamiento, el empalamiento y el garrote. ${ }^{55}$

La diversidad de tipos de ejecuciones de la pena de muerte que podemos reconocer, en un sentido lato, estaba condicionada por las diferencias de la violación al Derecho y por la condición social del delincuente.

Aunque algunos cronistas no precisan las varias formas de aplicación de la pena capital ni qué criterios guiaban el que se usara una u otra, podemos deducir varias circunstancias al respecto. Posiblemente el quemar vivo al reo a veces se usaba cuando la infracción era tal, que originaba una mayor atracción de las fuerzas maléficas, por lo que era necesario purificar a la comunidad. En la Relación de Tecauto y Tepacan se dice que: "ni usvan el pecado nefando y dizese que vn tutuexiu señor de mayapan por hallar cul-

54 Motul..., p. 504

55 Landa, op. cit., p. 53.

Chí, op. cit., p. 231.

Cogolludo, op. cit., Vol. I, p. 237.

Fray Jerónimo Román y Zamora, República de Indias. Idolatrías y gobierno en México y Perú antes de la Conquista, 2 vols., Victoriano Suárez Editor, Madrid, 1897; (Col. de libros raros y curiosos que tratan de América, XIV y XV); Vol. I, p. 308 y 312.

Las Casas,op. cit., Vol. II, p. 520. 
pados a vnos yndios en este pecado los mando quemar bibos en vn horno de cal y canto..." ${ }^{56}$ Fray Bartolomé de Las Casas narra que: "Cualquiera que era brujo o bruja, quemábanlo y llamábanlo en su lengua balan que quiere decir tigre... Estos hacían muchos daños, y por esto los quemaban..." 57

Hubo ciertas diferencias en lo que se refiere a la aplicación de la pena capital a personas de diferentes niveles sociales, ya fueran del pueblo o de la aristocracia. Al parecer, coherentes con el sentido maya de la justicia, y particularmente con su idea de la responsabilidad jurídica de la nobleza, no se les daba a ellos un trato preferencial sino que eran sometidos a las ejecuciones más infamantes. Asimismo, vemos que se apilcaban las penas más deshonrosas a los que cometían fechorías contra las jerarquías políticas o sacerdotales o cuando los objetos o lugares de los delitos tenían carácter sagrado. El más ignominioso castigo para un reo era el despeñamiento o sea, ser arrojado desde una colina; posiblemente, la deshonra de tal sanción consistía en que la muerte era lenta y el cuerpo quedaba deshecho. Algunos delitos a los que correspondía este castigo eran: el adulterio con la esposa o concubina del señor, el hurto de las cosas sagradas, la profanación de los templos y la desobediencia a las autoridades. ${ }^{58}$

Los cronistas hablan de una ejecución por ahorcamiento y otra por "garrote", pero no aclaran cómo era cada una de ellas; sabemos que eran dos formas distintas porque en un mismo texto son mencionadas como penas a diferentes violaciones. El latrocinio, el homicidio, el adulterio, el "simarrón" que había huido, la hechicería y la evasión del tributo eran algunas de las infracciones por las que acostumbraban ahorcar a los convictos. Alguna manera de estrangulación que fue llamada por los cronistas "garrote", o la muerte a palos, eran otras formas en que ejecutaban a los asesinos, adúlteros, plagiarios, ladrones y practicantes de la magia negra, cuando originaban la muerte, invalidez o esterilidad de alguna persona. ${ }^{59}$

Ciertas transgresiones a la ley, de las que sólo conocemos que tenían como castigo la muerte, sin ninguna otra aclaración referente a la pena, eran: la tiranía excesiva o crueldad de un gobernante, la malversación de fondos públicos, la traición, la conspiración, la práctica de la caza o pesca por un enemigo en territorio

56 Relaciones..., Vol. I, p. 122.

57 Las Casas, op cit., Vol. II, p 502.

58 Román y Zamora, op cit., Vol. I, p. 298.

Las Casas, op. cit., Vol. II, p. 502.

Fuentes y Guzmán, op. cit., Vol. I, p. 73.

s9 Las Casas, op cit., Vol. II, pp. 519, 520, 522. 
propio, la captura de quetzales sin autorización del gobierno, el menosprecio a algún aspecto de la religión y el plagio, entre otras.

$\mathrm{Al}$ parecer, cuando al delito le correspondía la pena capital traía aparejada lo que se ha llamado pena solidaria, o sea, que también eran castigados los miembros de la familia del reo, como ya hemos explicado. Esta es la condena más grave que hallamos.

El sacrificio ritual en honor de sus dioses no fue realizado nunca como una condena legal; aun cuando frecuentemente se tomaban esclavos para el sacrificio, debieron escoger de preferencia a aquéllos capturados en las guerras, y excepcionalmente a los que habían cometido violaciones al Derecho.

En todas las civilizaciones antiguas y modernas, las penas corporales han ocupado un lugar significativo dentro de las sanciones de los delitos; sin embargo, en el mundo maya nos encontramos que no eran comunes, sino al contrario, muy poco usuales; esto posiblemente se deba a la falta de un desarrollo jerárquico de las penas graves que hizo pocas las ocasiones en que se atenuaba la ejecución supliéndola con castigos físicos. Por el cronista de Indias Herrera y Tordesillas, sabemos que en Honduras le arrancaban las orejas a los adúlteros y que al ladrón "si el hurto era grande, le cortaban las orejas y las manos". ${ }^{60}$ Esta última sanción nos muestra que debió haber varias penas corporales en que se mutilaba la parte del cuerpo que había tenido una participación directa en la comisión del delito, lo que nos pone en evidencia su sentido mágico, ya que cercenaban aquella parte del cuerpo que había sido instrumento de las fuerzas malignas de los dioses.

Los mayas no concibieron la reclusión como castigo por las faltas a la ley, ya que no aceptaban que un hombre en plenitud de facultades permaneciera improductivo. No acostumbraban reducir la libertad de los individuos encerrándolos para que purgaran una condena, aunque solían poner en jaulas a los que iban a ser sacrificados; ${ }^{61}$ a estos reclusorios algunos cronistas les llamaron cárceles sin reparar en su exacto sentido, que es el que nos aclara Ciudad Real cuando refiere: "teníanlos a todos metidos en una cárcel ó red de maderos muy gruesos incados en tierra, y encima estaba hecha una barbacoa en que de noche dormían los que los

60 Antonio de Herrera y Tordesillas, Historia general de los hechos de los castellanos en las islas y tierra firme del mar Océano, 13 vols., notas Miguel G6mez del Campillo, Real Academia de la Historia, Madrid, 1934, Vol. 9, p. 231.

López Medel, Relación en Tozzer, op. cit., p. 22.

61 Chí, op. cit., p. 231. 
guardaban; de día los sacaban por el pueblo con unos cascabeles á los piés, y los regalaban y daban muy bien de comer, y les procuraban hacer fiestas, pero de noche volvían á la cárcel, en la cual estaban con la guardía sobre dicha, hasta que llegado el día del sacrificio sacaban a matar uno..." 62 Tampoco parecen haber usado algunas penas como el destierro, aunque el infame era proscrito de la comunidad, de tal manera que, seguramente se veía obligado a marcharse.

En ciertas situaciones, gran número de delitos tenían como castigo una manera de servidumbre que los españoles llamaron esclavitud, que podía ser temporal o perpetua, según la magnitud del hecho delictuoso. La única condición para que una persona de la misma comunidad fuera esclava, era haber cometido actos ilegales o ser cónyuge o hijo de algún individuo que, habiendo recibido la pena capital por su delito, fuera víctima de un castigo solidario; de este modo, cualquier persona, sin importar su condición social, edad o sexo, podía llegar a esta situación.

Dicha sanción consistía en que el Derecho limitaba la libertad del individuo, de tal manera que su fuerza de trabajo quedaba enajenada a la persona en cuyo perjuicio había sido cometido el delito. Si se trataba de un castigo solidario y la transgresión del pariente era valorada como un hecho contra toda la comunidad, como la traición o la profanación de un templo, posiblemente la persona iba a parar a casa de algún noble, donde quedaba a su servicio, o era llevada a vender como esclava en los mercados, quedando las ganancias para el erario públi$\mathrm{co}^{63} \mathrm{El}$ delincuente involucrado perdía el puesto público, si lo tenía, su condición social, su derecho a habitar con los de su linaje y, seguramente, su poder para el usufructo de la tierra; sin embargo, conservaba otras facultades como la de acumular bienes, realizar transacciones mercantiles, demandar ante las autoridades e incluso poseer otros esclavos, por lo que esta forma de servidumbre se nos presenta como una disminución de la personalidad jurídica y no una nulificación de ésta, como se dió en Roma, por ejemplo.

Estos malhechores eran utilizados en muy diversas tareas: los hombres trabajaban en las labores agrícolas, la caza, la pesca, como

62 (Fray Antonio de Ciudad Real), Relación breve y verdadera de algunas cosas de las muchas que sucedieron al padre fray Alonso Ponce en las provincias de la Nueva España, siendo comisario general de aquellas partes, Imprenta de la viuda de Calero, Madrid, 1872; (Col. de Documentos inéditos para la his. toria de España, LVII y LVIII); Vol. I, p. 474.

63 Fuentes y Guzmán, op. cit., Vol. I, p. 73. 
mensajeros, cargadores y hasta remeros; las mujeres participaban de las labores domésticas moliendo maíz o cocinando. ${ }^{64}$

La forma más leve de esclavitud era aquélla a la que se sometía la adúltera reincidente, ya que pasaba a ser esclava de su esposo, con lo que su vida no cambiaba radicalmente; seguía empeñada en el trabajo doméstico, aunque ahora con el peligro de ser vendida o pasar a la calidad de concubina cuando su esposo tomara a otra como cónyuge. ${ }^{65}$

Los que cometían alguna irreverencia leve, hurtaban alguna cosa o habían sido sometidos por transgresiones al Derecho cometidas por algún familiar, podían comprar ellos mismos o sus parientes, su libertad, pagando lo robado en el caso de los ladrones o dando a las autoridades el valor comercial de un esclavo. ${ }^{66}$

La servidumbre perpetua y sin posibilidad de redención, caía sobre aquellos cuyo delito merecía la pena de muerte, pero le era condonada, ya sea por no estar suficientemente probada su culpabilidad o por ser menor de edad; ${ }^{67}$ igualmente aquellos parientes de los que eran ejecutados por el hurto de cosas sagradas, desobediencia u ofensa a los sacerdotes, profanación de los templos, malversación de los fondos de los tributos, excesiva crueldad y tiranía de los gobernantes, así como la familia de los que traicionaban a los señores, a su comunidad o descubrían sus secretos, se amotinaban o conspiraban contra la autoridad. ${ }^{68}$

Landa expresa que los señores y los jueces mandaban dar "satisfacciones" a los agraviados, ${ }^{69}$ lo que pone de manifiesto el concepto de composición que estuvo presente en el Derecho maya; o sea, creían necesario que el perjuicio material ocasionado fuera reparado por el causante. El pago debía ser igual o equivalente al valor de lo perdido, y su costo era dado por el delincuente, su familia o su pueblo, de acuerdo con las reglas que tradicionalmente se habían seguido. Numerosos hechos delictuosos debieron haber tenido la posibilidad de arreglos privados, ya sea entre los directamente involucrados o sus familias.

Cuando se interponía una demanda, va configurado el delito, el juez tenía la posibilidad de proponer una compensación como sentencia; la parte actora podía rechazarla y exigir un castigo mayor,

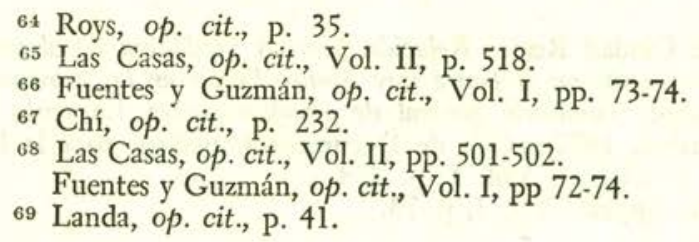


así, "La pena del homicida aunque fuese casual, era morir por incidias de los parientes, o si no, pagar el muerto". ${ }^{70} \mathrm{La}$ indemnización también se usaba en hurtos de cosas de poco valor y sin carácter sagrado, así como en determinadas cuestiones de relaciones sexuales ilícitas, como "El mancebo que fornicaba con alguna doncella, no le daban otra pena sino compelelle a que la tomase por mujer. $\mathrm{Si}$ la doncella estaba desposada con otro, no la tomaba su esposo ni la vía más, sino pedía que le restituyesen su dote o arras o precio que había dado, el cual pagaba el que había corrompido y adulterado la doncella, dándolo al padre y a la madre della". ${ }^{71}$

En la sociedad maya la conducta del hombre era vigilada constantemente por toda la comunidad, quien la evaluaba de tal forma que si la aprobada o desaprobada redundaba en beneficio o en perjuicio del individuo, ya sea dignificando su personalidad y dándole la posibilidad de mejorar su condición en algún sentido, o al contrario, recayendo la infamia sobre él y cerrándole las alternativas de mejorar.

Todas las formas de coacción legal que hasta ahora hemos mencionado llevaban aparejadas una gran dosis de deshonra pública, que no sólo caía en la persona del inculpado sino también en su familia y algunas veces en todos los miembros de su linaje, para lo cual todas las sentencias se hacían públicas como ya ha quedado dicho.

Había algunos delitos leves que sólo merecían penas cuya finalidad era la vergüenza del culpable, éstas eran las marcas y las amonestaciones públicas. En cuanto a las primeras contamos con el testimonio de Landa acerca del que robaba, si era señor "juntábase el pueblo y prendido el delincuente le labraban el rostro desde la barba hasta la frente, por los lados en castigo que tenían por gran infamía". ${ }^{72}$ La escarificación producida en la cara de los nobles mayas debió tener algún diseño que pusiera de manifiesto las malas acciones cometidas, ya que gente de todas las clases sociales usaba adornarse la cara con tatuajes; al que recibía este castigo le quedaba una marca indeleble que le sujetaba a la excecración permanente.

Algunas veces exponían a los reos a la deshonra desnudándolos o cortándoles el cabello; ${ }^{73}$ la afrenta duraba mientras estuviera en la memoria de la comunidad y se acostumbraba hacerlo

70 Ibidem, p. 53.

71 Las Casas, op. cit., Vol. II, p. 521.

72 Landa, op. cit., p. 53.

73 Chí, op. cit., p. 232. 
con los sospechosos a los que no se podía probar nada. Las penas infamantes podían ser accesorias ya que iban unidas a otras de diversos caracteres; generalmente de este género eran las reprimendas que los jueces hacían a todos aquellos delincuentes que eran objeto de diversas sanciones de diferentes tipos de gravedad, de muchas que podemos citar "la pena que se daba al que se probaba haber mentido o levantado falso testimonio, era que le reñía el señor ásperamente y deshonraba de palabra, y mandábale que pagase diez o quince o veinte plumas, según que le parecía". ${ }^{74}$

La primera manifestación de las penas pecuniarias aparece en las sociedades en su expresión de la confiscación de bienes, siendo entre los mayas solamente una sanción accesoria de los delitos graves; así, ellos la veían como una extensión de la pena capital, por ejemplo en el caso del "que cometía crimen de traición contra el señor o su república y descubría los secretos della, o se pasaba a los enemigos, mataban y confiscábanle todos sus bienes, y a sus hijos y mujeres hacían esclavos". ${ }^{75} \mathrm{El}$ alcance de dicha acción legal debió consistir en anular todos los derechos que sobre bienes muebles e inmuebles tenía el malhechor y su familia; posiblemente, todos sus implementos de trabajo y de uso doméstico pasaban a los fondos públicos, así como las tierras que poseían o usufructuaban.

Sólo cuando, dentro de la organización política de una sociedad, la justicia queda totalmente en manos de autoridades especiales pertenecientes a la jerarquía gobernante y hay un sistema organizado de manejo de los fondos públicos, y en otro sentido, cuando ya existe un amplio desarrollo jerárquico en la gradación de los delitos, aparece la multa. Entre los mayas la imposición del pago de una determinada cantidad a las autoridades públicas era una sanción muy común tanto en Yucatán como en Guatemala. Este pago se hacía en especie; según la decisión del juez debían pagar: plumas, mantas o cacao y se entregaba posiblemente al batab, ya que Las Casas asevera que: "El que hurtaba, lo punían con pena pecuniaria y esta pena era para el rey y su fisco, allende que había que restituír a su dueño lo hurtado". ${ }^{76}$ La cuantía de las multas era muy diversa, parece que en la tasación intervenía el criterio del juez y la tradición que había determinado más o menos la cantidad que debía pagar cada infractor; así, sabemos que los delitos de fornicación con casada, viuda, soltera y esclava ajena tenían como una alternativa

74 Las Casas, op. cit., Vol. II, p. 523.

75 Ibidem, p. 502.

76 Ibidem, p. 503. 
de pena el pago de 60 a 100 plumas y que el procesado por mentiras o falsos testimonios tenía que dar 15 o 20 plumas. En estos casos podía ser la pena principal, pero en otros como el hurto era el castigo accesorio, ya que la sanción fundamental consistía en regresar lo robado o dar una indemnización equivalente al agraviado. ${ }^{77}$

\section{CONCLUSIONES}

Los diversos cronistas que se refieren a la cultura maya legaron alguna información, ciertamente escasa y poco precisa, acerca de aquellas conductas que desencadenaban una acción punitiva de la sociedad, por ser violatorias de las normas fundamentales que, de acuerdo con un criterio antropológico, pueden ser consideradas como pre. ceptos jurídicos. Después de reunir dichos testimonios y analizarlos, propusimos algunas de las características generales que predominaban en lo que podríamos llamar Derecho Penal maya en el siglo XVI y que nos han permitido demostrar la invalidez de considerar al Derecho maya como primitivo.

Una semejanza esencial en los mecanismos legales de los pueblos mayances de diversas zonas, nos dio la pauta para poder establecer un esquema general válido para los mayas de ese momento.

En dichos pueblos, la costumbre era la más importante integradora del Derecho; esta reiteración de formas de acción contra la delincuencia había formado una tradición compleja de sólidos patrones, y no eran sólo las diversas reacciones particulares ante ciertas agresiones, sino el modelo explícito y definido de respuesta social ante las violaciones a la ley. Las nuevas necesidades de una organización socio-política más compleja, los obligaron a dictar normas que no contemplaba el Derecho consuetudinario, apareciendo los preceptos de origen legislativo, que denotan un progreso en la evolución de formas más simples de normas jurídicas.

Los mecanismos para el castigo de los delitos no eran manejados por el afectado, como sucede en el Derecho primitivo, sino por personas e instituciones del gobierno que formalmente eran las depositarias de la autoridad necesaria para ello.

En el campo de la justicia, como en muchos otros aspectos del gobierno, el halachuinic tenía los mayores poderes incluso con derecho a vetar decisiones de otras autoridades; sin embargo no monopolizaba dicho aspecto del poder, sino que lo delegaba en diversas autoridades

77 Fuentes y Guzmán, op. cit., Vol. I, p. 73. 
como el batab, que tenia muy amplias facultades jurídicas, tanto para legislar para la comunidad que gobernaba, como para castigar a los malhechores, pero no tenía poder en cuestiones entre personas de diferentes comunidades o en asuntos en los que él o su poder, de alguna manera, estuvieran involucrados. Había casos en que el batab no dependía de ningún jefe territorial por lo que gozaba de los más absolutos poderes como el halach uinic.

Los ah kuleloob no tenían funciones legislativas, pero en parte y con poderes limitados ejecutaban ciertas labores jurídicas del batab, en asuntos cuya competencia abarcaba oír pleitos y demandas, dirigir las conciliaciones e imponer sanciones que no excedieran a indemnizaciones, multas, castigos infamantes y castigos corporales, siempre y cuando fueran asuntos del común del pueblo, ya que las cuestiones cuyo castigo fuera la esclavitud o la muerte y en las que estaban mezclados los almehenoob eran turnadas a las autoridades superiores. Hemos podido observar que la complejidad del aparato jurídico de los mayas era tal que había dado origen a los tupiloob; empleados burocráticos que estaban involucrados en la justicia al servicio de los ah kuleloob sin tener ningún tipo de autoridad.

Partiendo del concepto de tribunal que expresamos al principio, distinguimos tres diferentes tipos de ellos: el reunido por el $a h$ kulel, con la competencia ya dicha, que funcionaba generalmente como corte de arbitraje; aun cuando era un tribunal temporal, la existencia de una autoridad responsable de llevar el caso hasta su fin o de turnarlo a otro, cuando se declaraba incompetente, implica un paso importante en la integración de un sistema legal. Sin embargo, los mayas fueron más allá, teniendo sistemas más evolucionados en los tribunales judiciales compuestos por el batab y sus consejeros y el halch uinic y los suyos, con verdaderos magistrados que, además de desempeñar otras actividades gubernamentales, colegiados, tenían poderes específicos en el aspecto jurídico.

En la sociedad maya la justicia era en gran medida un monopolio del gobierno; sin embargo, las supervivencias de un sistema más antiguo se ponen de manifiesto en la limitación de los casos perseguidos por la justicia por su propio fuero, y por lo tanto, la posibilidad de negociaciones particulares en actos que pueden ser considerados ilegales y, en determinadas cuestiones, en la libre decisión de los perjudicados para acudir a las autoridades.

En lo referente a los procesos, había el intento de un convencimiento preciso de la comisión del delito, valiéndose las autoridades 
del examen de un gran número de pruebas presuncionales, confesionales, testimoniales y evidencias materiales, lo que es una muestra más de la evolución del sistema jurídico maya. No tenemos información acerca de la utilización de pruebas mágico-religiosas para comprobar el hecho delictuoso, posiblemente se deba a una omisión de los cronistas a causa de su pensamiento jurídico secular, pero opinamos que ya no las usaban, por lo que nos encontramos ante la superación de una búsqueda de evidencias mágicas que existieron en muchos Derechos rudimentarios, sobre todo de pueblos en que prevalecen las convicciones religiosas.

Una de las particularidades más relevantes del Derecho maya, considerada como revolucionaria en la formación de los sistemas legales, es que, probado el delito, además de considerar los resultados objetivos del acto, analizaban el grado de culpabilidad de la persona, tomando en cuenta como atenuantes las causas anímicas del hecho delictivo, como la falta de intención, la negligencia y la provocación. También consideraban al menor de edad como incacapaz de una comprensión racional de la violación al Derecho y a la mujer le disminuían la culpa por deferencia a su femineidad, aunque esto no es muy claro debido a la falta de precisión en las fuentes.

El estricto deber de poner los modelos de conducta que la colectividad debía seguir, originó que los individuos pertenecientes a un alto status social tuvieran una mayor responsabilidad jurídica ante la comunidad, lo que expresa la desigualdad ante la ley, como otra de las características peculiares del Derecho maya. Así, el ser almehen redundaba en perjuicio del delincuente; también eran agravantes de su posición la reincidencia, que producía acumulación de la pena y el carácter sagrado de los objetos o lugares violados.

Dentro de las varias supervivencias de una estructura legal primitiva en el Derecho maya, encontramos la responsabilidad solidaria, ya limitada sólo a la familiar directa del malhechor y aplicada en casos de suma gravedad.

La conclusión de un proceso penal era la publicación de la sentencia y la ejecución de la pena, que en esta sociedad ya había superado la concepción de la reparación privada o venganza personal, ante el nuevo pensamiento de la protección de la comunidad y la intención de reprimir las voluntades delictivas. Las conductas antisociales eran castigadas por los mayas de diversas maneras más o menos rigurosas, sin embargo hemos visto que ya no existía entre ellos el talión, aunque procuraban la restitución con métodos de composición más suaves, autorizados y vigilados por el Estado para 
delitos que iban desde el asesinato hasta, en circunstancias particulares, robos simples. Encontramos una gran diversidad de métodos de punición que se aplicaban en función de la magnitud del delito, incluso en cada uno de ellos hay un desarrollo jerárquico de los castigos. Acostumbraban condenar a los reos a la pena capital, ejecutada de diversas maneras según la gravedad del delito y el estamento social del delincuente, imponiendo las más infamantes a las violaciones más graves y a los almehenoob.

$\mathrm{La}$ atenuación de la muerte por castigos físicos tuvo muy poco in. cremento y sólo hay limitadas noticias de mutilaciones corporales. Otra pena de importante magnitud impuesta a la familia de algunos condenados a muerte y a diversos malhechores, era lo que los españo. les llamaron esclavitud; que consistía en la enajenación temporal o perpetua de la fuerza de trabajo del delincuente y la reducción de sus derechos legales, todo lo que puede ser considerado como un cambio de condición en la sociedad.

$\mathrm{La}$ infamia recaía sobre todos los delincuentes que eran procesados, pero había sanciones específicas que implicaban un estigma para la persona, como el rapado, el tatuado o la exhibición del reo desnudo; la más leve deshonra era la reprimenda pública. Entre las sanciones pecuniarias que los mayas usaban aplicar tenemos la confiscación de bienes, como castigo solidario para la familia de los condenados a muerte por graves delitos y las multas, cuya utilización sólo aparece en pueblos en que el Derecho es manejado por instituciones del gobierno que administraban los caudales del Estado. Dicho castigo era la sanción de las autoridades después del acuerdo de restitución o indemnización; a veces era el castigo primario cuando no había posibilidad de composición como en los delitos contra el honor sexual.

A diferencia de las demás instituciones de los mayas, que están impregnadas del sentido religioso que dominaba la vida de la comunidad, el Derecho lo hemos visto algo secularizado. Excepto el halach uinic y el batab que eran gobernantes civiles y religiosos, los demás sacerdotes no parecen haber tenido potestad jurídica, así como la autoridad dedicada más especialmente a la justicia, el ah kulel, no tuvo atribuciones religiosas; lo que implica un importante desarrollo de la división de funciones. Por otro lado, las violaciones a ciertas costumbres religiosas no tenían el rango de delitos, y su castigo estaba relegado a la acción de las fuerzas sobrenaturales. Tampoco las sanciones parecen estar impregnadas de un sentido ritual, sino más bien se nos presentan como ejecuciones civiles. Es innegable que había cierto grado de secularización, pero no sabemos 
hasta qué punto fue realmente así, por lo impreciso de los testimonios y por la información de los cronistas, desvirtuada por su propia visión occidental de las instituciones.

Los elementos del Derecho Penal que hemos señalado, constituyen una de las muchas expresiones de la evolución política gestada en las comunidades mayas. Lawrence Krader establece que las formas de gobierno de una sociedad se transforman pasando por diversas etapas de integración. Según su concepción una comunidad puede ser considerada como Estado, cuando el poder coercitivo ha sido centralizado y monopolizado en una autoridad oficial representada por instituciones estables y explícitas, en cuyas manos está impedir la violación de las normas que la sociedad ha sancionado como leyes. ${ }^{78}$ De esta forma podemos decir que el Derecho maya nos proyecta una cultura en que válidamente podemos hablar de Estado.

\section{BIBLIOGRAFIA}

Cassin, Elena.

1972 et al., Los imperios de antiguo oriente. Del paleolítico a la mitad del segundo milenio, 3a. ed., Siglo XXI, México; (Historia Universal Siglo XXI, 2).

(Ciudad Real, Fray Antonio de)

1872 Relación breve y verdadera de algunas cosas de las muchas que sucedieron al padre fray Alonso Ponce en las provincias de la Nueva España siendo comisario general de aquellas partes, Imprenta de la viuda de Calero, Madrid; (Col. de Documentos inéditos para la historia de España, LVII y LVIII).

1929 Mérida.

Chí, Gaspar Antonio

1941 Relación: en Landa's Relación de las cosas de Yucatán, pp. 230-232, Papers of the Peabody Museum of American Archaeology and Ethnology, Harvard University, Vol. XVIII, Cambridge Mass.

Fuentes y Guzmán, Francisco Antonio de

1969 Recordación florida en: Obras históricas de..., Ed. y

1972 estudio preliminar Carmelo Sáenz de Santa María, 3 vols., Atlas, Madrid; (Biblioteca de Autores Españoles desde la formación de la lengua hasta nuestros días, 230, 251, 259).

78 Lawrence Krader, La formación del Estado, trad. Jesús Fomperosa Aparicio, Labor, Barcelona, 1972; (Nueva Colección Labor, 139). 
Herrera y TORdesillas, ANTONIO de

1934 Historia general de los hechos de los castellanos en las islas y tierra firme del mar Océano, 13 vols., notas Miguel Gómez del Campillo, Real Academia de la Historia, Madrid.

Hoebel Edward, Adamson

1954 The law of primitive man. A study in comparative legal

KRADER, LAWRENCE dynamics, Harvard University Press, Cambridge Mass.

1972 La formación del Estado, trad. Jesús Fomperosa Aparicio,

Landa, Fray Diego de Labor, Barcelona; (Nueva Colección Labor, 139).

1966 Relación de las cosas de Yucatán, 9a. ed., introd. Ångel María Garibay, Porrúa, México; (Biblioteca Porrúa, 13).

Las Casas, Fray Bartolomé de

1967 Apologética historia sumaria, Ed. prep. por Edmundo O'Gorman, 2 vols., Instituto de Investigaciones Históricas, UNAM, México: (Serie de Historiadores y Cronistas de Indias, 1).

López Austin, Alfredo

1961 La constitución real de México Tenochtitlan, Instituto de Historia: Seminario de Cultura Náhuatl, UNAM, México.

López Cogolludo, Fray Diego de

1971 Los tres siglos de la dominación española en Yucatán o sea Historia de esta Provincia, 2 vols., Akademische Druck Verlagsanstalt, Graz Austria.

MaLinowsKi, BronisLaW

1971 Crimen y costumbre en la sociedad salvaje, 3a. ed., trad. M. T. Alier, Ediciones Ariel Barcelona; (Col. Ariel Quincenal, 15).

RADCLIFF-Brown, A.R.

1974 Estructura y función en la sociedad primitiva, 2a. ed., trad. Ángela Pérez, pról. E. A. Evans Prichard y Freg Eggan, Ediciones Península, Barcelona; (Historia, Ciencia y Sociedad, 9).

Relaciones histórico geográficas de las Provincias de Yucatán en: Col.

1898-1900 de Documentos inéditos relativos al descubrimiento, conquista y organización de las antiguas posesiones de Ultramar, 2a. Serie, vols. 11 y 13, Establecimiento Tipográfico Real Academia de la Historia, Madrid.

Romín y Zamora, Fray Jerónimo de

1897 República de Indias. Idolatrías y gobierno en México y Perú antes de la Conquista, 2 vols., Victoriano Suárez Editor, Madrid; (Col. de libros raros y curiosos que tratan de América, XIV y XV).

ROYS, RALPH

1965 "Lowland maya native society at spanish contac", en Handbook of Middle American Indians, Vol. 3, University of Texas Press, Austin. 
Tozzer, Alfred M.,

1941 Landa's Relación de las cosas de Yucatán, A translation, Edit. with notes, Papers of the Peabody Museum of American Archaeology and Ethnology, Vol. XVIII, Harvard University, Cambridge, Mass.

\section{Trimborn, German}

1968 El delito en las altas culturas de América, Universidad Nacional Mayor de San Marcos, Lima, Perú; (Comentarios del Perú, 9). 